BARBARIANS AND ROMANS, A.D. 418-584 
BARBARIANS

A.D. $418-584$

THE TECHNIQUES OF ACCOMMODATION

BY WALTER GOFFART

PRINCETON UNIVERSITY PRESS 


\section{AND ROMANS}

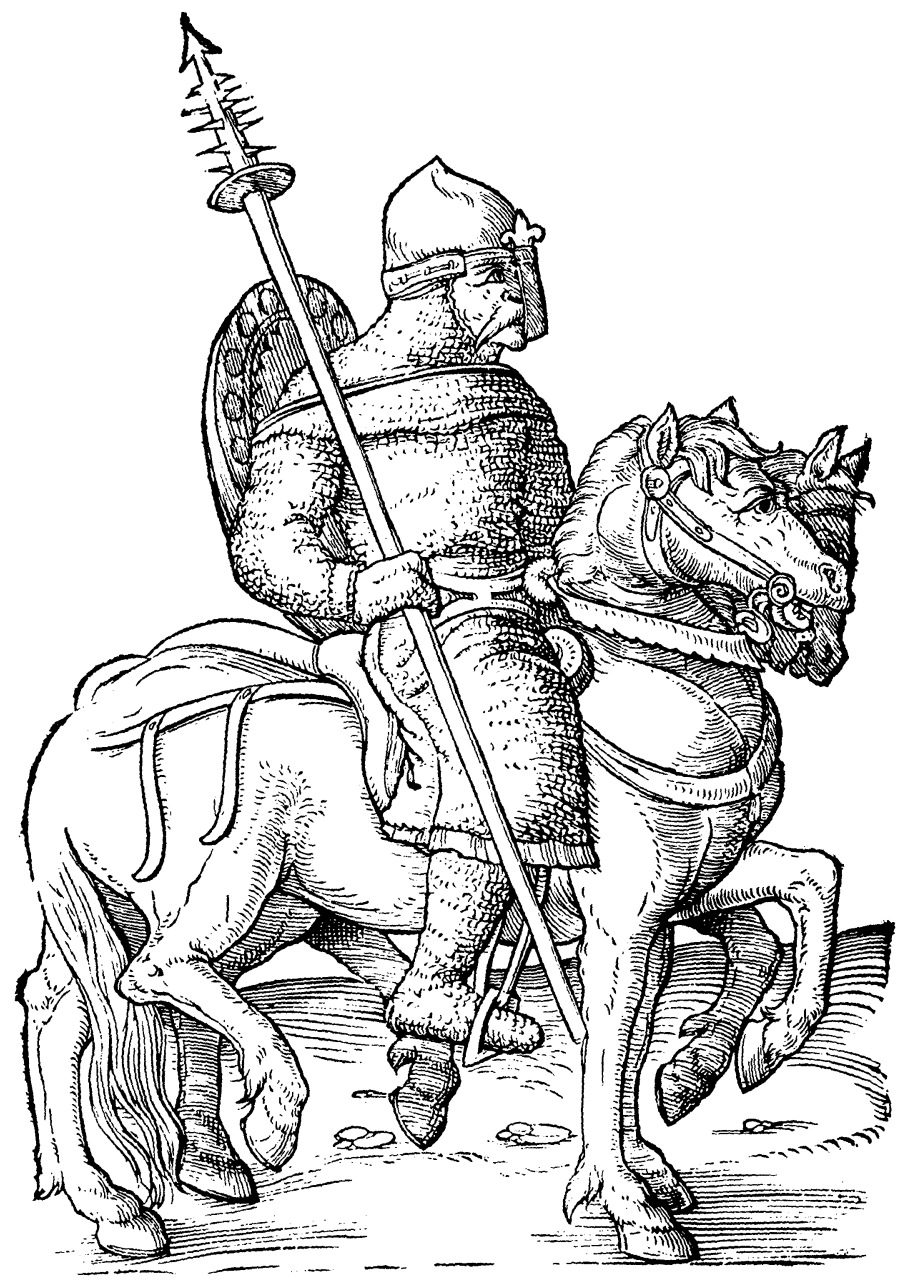


COPYRIGHT (C) 1980 BY PRINCETON UNIVERSITY PRESS PUBLISHED BY PRINCETON UNIVERSITY PRESS, PRINCETON, NEW JERSEY

IN THE UNITED KINGDOM: PRINCETON UNIVERSITY PRESS, CHICHESTER, WEST SUSSEX

\section{ALL RIGHTS RESERVED}

Library of Congress Cataloging in Publication Data

GOFFART, WALTERA

BARBARIANS AND ROMANS, A.D. $418-584$.

INCLUDES INDEXES.

1 ROME-HISTORY - GERMANIC INVASIONS, 3 D-6TH CENTURIES. 2. ROME-FOREIGN POPULATION.

3. ACCULTURATION-ROME. I. TITLE.

$$
\begin{gathered}
\text { DG319.G63 } 940.11^{\prime} \quad 80-7522 \\
\text { ISBN } 0-691-05303-0 \\
\text { ISBN } 0-691-10231-7 \text { (PBK.) }
\end{gathered}
$$

PUBLICATION OF THIS BOOK HAS BEEN AIDED BY THE LOUIS A. ROBB FUND OF PRINCETON UNIVERSITY PRESS THIS BOOK HAS BEEN COMPOSED IN LINOTYPE CALEDONIA

PRINCETON UNIVERSITY PRESS BOOKS ARE PRINTED ON

ACID-FREE PAPER AND MEET THE GUIDELINES FOR PERMANENCE AND DURABILITY OF THE COMMITTEE ON PRODUCTION GUIDELINES FOR BOOK LONGEVITY OF THE COUNCIL ON LIBRARY RESOURCES

PRINTED IN THE UNITED STATES OF AMERICA

THE DRAWING ON THE FRONTISPIECE IS FROM De gentium migrationibus (BASLE, 1557) BY WOLFGANG LAZIUS $(1514-1565)$, COURT PHYSICIAN AND HISTORIOGRAPHER TO THE AUSTRIAN HAPSBURGS. THE TITLE OF THIS BOOK ESTABLISHED “MIGRATIONS OF PEOPLES" (IN GERMAN, Völkerwanderung) AS AN ALTERNATIVE TO

"BARBARIAN INVASIONS." COPY FROM THE LIBRARY OF WILLIAM H. SCHEIDE. 
TO ROBERTA 
